\title{
AIR CHIEF MARSHAL SIR ROBERT BROOKE-POPHAM \\ G.C.V.O., K.C.B., C.M.G., D.S.O., A.F.C.
}

\section{$\dagger$}

Ir is with a deep sense of regret that we record the death of Air Chief Marshal Sir Robert Brooke-Popham, who was Chairman of the British School of Archaeology in Iraq from 1950-1954. He had served this country with high distinction, and even after his retirement was busied with a great variety of duties, voluntarily performed. Nevertheless, when the Chairmanship of the School fell vacant, he felt it incumbent on him to accept that office, although he was already fully occupied.

Sir Robert had been interested in archaeology throughout his life, and wherever he served abroad, made himself acquainted with what had been done in that field. Whilst in Kenya he wrote many notes about Leakey's discoveries concerning the Old Stone Age; at home he was a frequent visitor to Avebury. His interest in the archaeology of Iraq went back to the years of his service in 1929-1930, when he followed keenly the work which was being done at Ur. On several occasions he visited the dig, accompanied by Lady Brooke-Popham, who shared in his enthusiasm for antiquity. After the second World War he attended lectures at the School in London when its activities were resumed, and at the end of the first meeting asked the lecturer to send him his manuscript, for his imagination had been rouscd by a discussion of Babylonian temples and religion. When he became Chairman, he had the satisfaction of watching the fruitful discoveries made by the School's expeditions in Assyria; his delight at seeing beautiful things pass through his hands was a pleasure to witness.

He will be remembered by those who knew him with affection, by others with respect. To archaeologists, the active interest shown by busy men who have held high offices of State, such as he, is a grateful encouragement. $\mathrm{He}$ recognised that from the past we have been endowed with a deep and abiding heritage which, if wisely husbanded, can be used for the material and spiritual profit of mankind. In him there lay a genuine feeling for the scholarly approach, and for the permanent value of learning. We extend to his widow our deep sympathy for the loss of one whose membership the School records with pride, and with gratitude. 